\title{
Greenhouse Mist Improves Yield of Tomato Plants Grown under Saline Conditions
}

\author{
R. Romero-Aranda, ${ }^{1}$ T. Soria, and J. Cuartero \\ Estación Experimental La Mayora, Consejo Superior de Investigaciones Científicas, 29750 Algarrobo- \\ Costa, Málaga, Spain
}

\begin{abstract}
ADDITIONAL INDEX wORDS. Lycopersicon esculentum, salt stress, plant water uptake, water relations, gas exchange, yield
Abstract. High salinity levels in irrigation water available in Mediterranean coastal areas induce a significant loss of yield in greenhouse tomato crops. This loss increases during the spring-summer growing season when high irradiance, temperature, and low humidity occur within greenhouses. This study determined whether salt-induced yield losses could be alleviated by increasing humidity by misting the greenhouse atmosphere. Plants of 'Daniela' tomato (Lycopersicon esculentum Mill.), were irrigated with 0 or $50 \mathrm{~mm} \mathrm{NaCl}$ added to the nutrient solution and grown under natural greenhouse conditions or under applications of fine mist every 8 min during the day. During midday hours, misting reduced greenhouse air vapor pressure deficit 1.0 to $1.5 \mathrm{kPa}$ and reduced greenhouse air temperature 5 to $7^{\circ} \mathrm{C}$. Mist reduced root water uptake from the medium by $40 \%$ in nonsalinized plants and by $15 \%$ in saline conditions. Foliar concentration of $\mathrm{Na}$ was lower in misted-salinized plants than in nonmisted salinized plants. Less negative leaf water potential and higher leaf turgor were recorded with mist at midday, in both salinized and nonsalinized plants. Midday stomatal conductances and net $\mathrm{CO}_{2}$ assimilation rates of salinized-misted plants were 3 and 4 times higher, respectively, than those recorded in salinized-nonmisted plants. Misted plants increased instantaneous water use efficiency $84 \%$ to $100 \%$, as estimated from the ratio of net $\mathrm{CO}_{2}$ assimilation to transpiration. Nonsalinized plants grown with mist increased total leaf area by $38 \%$, dry matter by $10 \%$, and yield by $18 \%$ over nonmisted plants. Salinized plants grown with mist increased total plant leaf area by $50 \%$, dry matter by $80 \%$, and yield by $100 \%$. Greenhouse misting resulted in a saving of total water input of $31 \mathrm{~L} /$ plant under nonsaline conditions and in greater yields and fruit size regardless of salinity. Results suggest that greenhouse misting, during the Mediterranean spring-summer growing season, improves tomato crop productivity both under nonsaline and saline growth conditions.
\end{abstract}

Tomatoes (Lycopersicon esculentum) are an important greenhouse crop in semiarid coastal areas of Mediterranean countries. In these regions, soil and groundwater salinity are insidious problems that affect both tomato yield and quality (Cuartero and Fernadez-Muñoz, 1999). Greenhouse crops in these areas are also subjected to high radiation levels during the spring-summer which result in high temperatures and atmospheric vapor pressure deficits (VPDs) in the greenhouses (Stanghellini, 1994).

The balance between water uptake from the root medium and water loss from the stomata determines plant water status, which is usually expressed as total water potential and more recently as turgor water potential (Jones and Corlett, 1992). Turgor water potentials and stomatal conductance are modified by humidity (Nonami et al., 1990) and saline growth conditions (RomeroAranda et al., 2000). High evaporative demand by the atmosphere closes stomata (Monteith, 1995) and may induce water deficits in leaf mesophyll and epidermis (Grantz, 1990; Schulze, 1994). As VPD increases, leaf water potential decreases and leaf turgor goes to zero (Grammatikopoulus, 1999; Rhizopoulou, 1997). In wellirrigated greenhouse crops, if stomata close in response to large VPD, photosynthesis can decrease when there is enough water available in the soil to ensure normal transpiration rates. Low stomatal conductance can limit dry matter production, plant growth, and yield. Ranges of relative humidity $(\mathrm{RH})$ which tend to optimize crop yield have been defined in terms of air vapor pressure deficit $\left(\mathrm{VPD}_{\text {air }}\right)$ because it determines the water demand

Received for publication 27 Nov. 2000. Accepted for publication 2 Apr. 2002. This work was supported in part by EU contracts IC18-CT98-0266 and IC18CT98-0301. We thank M.C. Ruíz-Sánchez for allowing us to use the LI-COR 6200 photosynthesis system and Severiano Bolivar and Jerónimo Robles for assistance in greenhouse maintenance and water drainage collection. We are especially grateful to J.P. Syvertsen for valuable comments and helpful review of this manuscript.

${ }^{1}$ Corresponding author; e-mail rromero@eelm.csic.es. in the atmosphere and the water vapor differences between roots and leaves (Grange and Hand, 1987).

Although toxic effects of salinity on tomato plant growth and yield are widely described, salinity-induced alteration of tomato plant water relations are much less frequently studied (RomeroAranda et al., 2000). In particular, there is no information available about tomato plant performance under the combined effect of soil salinity and VPD in the greenhouse. The following research was designed to determine the climatic conditions within the greenhouse during the spring-summer growing season and to examine to what degree a simple misting device might increase humidity and low VPD in the greenhouse. We hypothesized that increased greenhouse humidity would improve water relations parameters, growth, and yield of tomato plants grown under moderate saline conditions.

\section{Materials and Methods}

Plant material and growth Conditions. The study was conducted at the Estación Experimental La Mayora, Consejo Superior de Investigaciones Científicas, in southeast Spain. Plants of 'Daniela' tomato were grown from February to mid-July 1998, in a plastic greenhouse covered by thermic polyethylene $200 \mu \mathrm{m}$ thick. Individual plants were grown in 16-L plastic pots filled with gravel (particle size between 2.5 to $5 \mathrm{~mm}$ ). The crop was fertigated by drip irrigation with a solution of: $\mathrm{NO}_{3}^{-}, 12.0 ; \mathrm{NH}_{4}{ }^{+}$, 0.5; $\mathrm{P}, 1.5 ; \mathrm{K}^{+}, 7.0 ; \mathrm{Ca}^{2+}, 4.0 ; \mathrm{Mg}^{2+}, 2.5 ; \mathrm{SO}_{4}{ }^{-}, 2.0 ;$ and $\mathrm{HCO}_{3}{ }^{-}, 0.5$ $\mathrm{mol} \cdot \mathrm{m}^{-3}$ adjusted to $\mathrm{pH} 5.5$ (Cánovas, 1995). Irrigation was computer controlled to provide all plants the same volume of nutrient solution regardless of saline or mist treatments. Pest and disease control followed standard commercial practices. All side shoots were removed as they appeared.

The greenhouse was divided in two compartments by a plastic screen. In one of them was installed a simple mist device con- 
structed with pipes ( $25 \mathrm{~mm}$ diameter), placed $1 \mathrm{~m}$ over the plants between the rows of the crop. Sprinklers (Orbitor, Copersa, Barcelona, Spain), providing a water flow of $7 \mathrm{~L} \cdot \mathrm{h}^{-1}$ at a pressure of $0.3 \mathrm{MPa}$, were placed on the pipes at $1-\mathrm{m}$ intervals. Mist treatment with rain water was applied daily from 0800 to $2000 \mathrm{HR}$, from 16 Apr. to the end of the experiment, 20 July. The misting system was computer controlled to operate $10 \mathrm{~s}$ every $8 \mathrm{~min}$.

Salinity treatments of 0 or $50 \mathrm{~mm} \mathrm{NaCl}$, were added to the nutrient solution and applied from 25 Feb., when plants had four to five true leaves, to the end of the experiment in July. The experimental design was a split plot with two fixed mist treatments (mist and no mist) as main plots and two fixed salinity levels $(0$ and $50 \mathrm{~mm} \mathrm{NaCl})$ as subplots with five replications as sub-subplots following the model $t_{j k l}=\mu+m_{j}+s_{k}+m_{(j k) 1}$ where $\mathrm{t}_{\mathrm{jk} \mathrm{i}}$ is the measured value for the $\mathrm{j}$ mist treatment and the $\mathrm{k}$ salinity level in the repetition $1, \mu$ is general average, $m_{j}$ is the average value of mist $\mathrm{j}(\mathrm{j}=2), \mathrm{s}_{\mathrm{k}}$ is the average value of the salinity level $\mathrm{k}(\mathrm{k}=2)$, and $\mathrm{ms}_{(\mathrm{jk}) 1}$ is the interaction between mist treatment $\mathrm{j}$ and salinity level $\mathrm{k}(\mathrm{l}=5)$. There were 55 plants for each salinity and mist treatment for a total of 220 plants. Humidity and air temperature in the two greenhouse compartments were recorded continuously by a data logger (Meteodata-256; Geonica, Madrid, Spain). $\mathrm{RH}$ was used to calculate air $\mathrm{VPD}_{\text {air }}\left[\mathrm{VPD}_{\mathrm{air}}=e_{\mathrm{sat}}\left(T_{\mathrm{air}}\right)-e_{\mathrm{a}} ; e_{\mathrm{a}}=(\mathrm{RH}\right.$ $\left.\times e_{\text {sat }}\right) / 100$, where $e_{\text {sat }}$ is the saturating vapor pressure at a particular air temperature, $e_{\mathrm{a}}$ the actual air vapor pressure, and $\mathrm{RH}$ the relative humidity].

Water Relations. Plant water uptake from the root medium was measured weekly during the experimental period, as the difference between the volume of nutrient solution supplied and the leachate collected. Five plants per salt and mist treatment were used for these measurements.

Leaf water potential $\left(\Psi_{\mathrm{w}}\right)$ and leaf osmotic potential $(\Psi \pi)$ were measured 2 weeks after the beginning of mist treatment (April) and again when plants had begun developing fruit at the beginning of June. $\Psi_{\mathrm{w}}$ and $\Psi \pi$ were measured on young, fully expanded leaves (at the $7^{\text {th }}$ to $9^{\text {th }}$ nodes from the apex). Fully turgid $\Psi_{w}$ was determined in the morning, between 0700 to $0800 \mathrm{HR}$, and at midday, between 1300 to $1400 \mathrm{HR}$, with a pressure chamber (Soil Moisture Equipment Corp., Santa Barbara, Calif.). After $\mathrm{Y}_{\mathrm{w}}$ was determined, the same leaves without midveins were frozen at -80 ${ }^{\circ} \mathrm{C}$. The samples were subsequently thawed and centrifuged at $4000 g_{\mathrm{n}}$ for $5 \mathrm{~min}$ to extract the cell sap. The osmotic potential of the leaf sap was measured with an automatic vapor pressure osmometer (model 5520; Wescor, Logan, Utah). Turgor potential $\left(\Psi_{\mathrm{p}}\right)$ was estimated as the difference between leaf water potential and osmotic potential. Five young fully expanded leaves were sampled in each salinity and mist treatment.

Net $\mathrm{CO}_{2}$ assimilation (A) and leaf transpiration rates $(\mathrm{E})$, calculated stomatal conductance $\left(\mathrm{g}_{\mathrm{s}}\right)$, and leaf-to-air vapor pressure deficit $\left(\mathrm{VPD}_{\text {leaf-to-air }}\right)$ were determined with a portable photosynthesis system (LI-6200; LI-COR Inc., Lincoln, Nebr.). Gas exchange measurements were made at midday between 1400 and $1600 \mathrm{HR}$, at the beginning of June, when plants had begun developing fruit, and when temperatures were highest in the greenhouse. An external fan (SUNON DP201A, CATA, Barcelona, Spain) provided cooling of the cuvette. Measurements were made at saturating photosynthetic photon flux of 950 to $1000 \mu \mathrm{mol} \cdot \mathrm{m}^{-2} \cdot \mathrm{s}^{-1}$. Five to 10 young, fully expanded leaves, of similar age as those used for measurements of leaf $\Psi_{w}$, were randomly selected for gas exchange measurements in each salinity and mist treatment. Leaf transpiration rates were used to calculate instantaneous leaf water use efficiency (WUE) as A/E.

Plant growth and yiEld. At the end of the experimental period, plant height and total number of leaves of five randomly selected plants per salinity and mist treatments were recorded. Fresh weights (FWs) and dry weights (DWs) of separated roots, stems, and leaves were also recorded. DWs were measured after drying plant parts for $3 \mathrm{~d}$ at $70^{\circ} \mathrm{C}$. Total leaf area was determined with an image analysis system (Delta-T, LTD, Cambridge, United Kingdom). Dried leaves were milled to powder for $\mathrm{Na}$ analysis with a flame photometer (Corning 410, Essex, United Kingdom) after digestion with $0.1 \mathrm{~N}$ acetic acid.

The first harvest of red-colored fruit was on 16 May and fruit were harvested weekly from this date until the end of the experiment. Total weight, number of fruit, and individual fruit weight were recorded every harvest.

Statistical ANALYSIS. Data were subjected to analysis of variance (ANOVA) procedures using SPSS/PC+ Statistics software package (SPSS 9.0, standard version 1995, SPSS, Inc. Chicago, Ill.). Means were separated, using Student-NewmanKeuls ( $\mathrm{S}-\mathrm{N}-\mathrm{K})$ test at $P<0.05$, and the CORR procedure of Pearson (SPSS/PC+ Statistics software package) was used for correlation analysis.

\section{Results}

ENVIronment AND Plant WATER UPTAKe. Within the greenhouse, mean $\mathrm{VPD}_{\text {air }}$ at midday in June when radiation was at the highest, was about $3 \mathrm{kPa}$ (Fig. 1). Greenhouse mist lowered these $\mathrm{VPD}_{\text {air }}$ values about $1.6 \mathrm{kPa}$. Mean values of maximum air temperature in the misted greenhouse compartment were $\approx 28{ }^{\circ} \mathrm{C}$, while temperatures $>35^{\circ} \mathrm{C}$ were recorded frequently at midday in the compartment without mist.

Daily plant water uptake increased from the end of March to the beginning of June and decreased thereafter (Fig. 2A and B). Maximum water uptake was recorded on nonsalinized plants grown without mist (Fig. 2A). The $50 \mathrm{~mm} \mathrm{NaCl}$ added to the nutrient

Fig. 1. Diurnal air vapor pressure deficit $\left(\mathrm{VPD}_{\text {air }}\right)$ within the nonmisted and misted greenhouse compartments in June when maximum air temperatures were $\approx 36$ ${ }^{\circ} \mathrm{C}$.

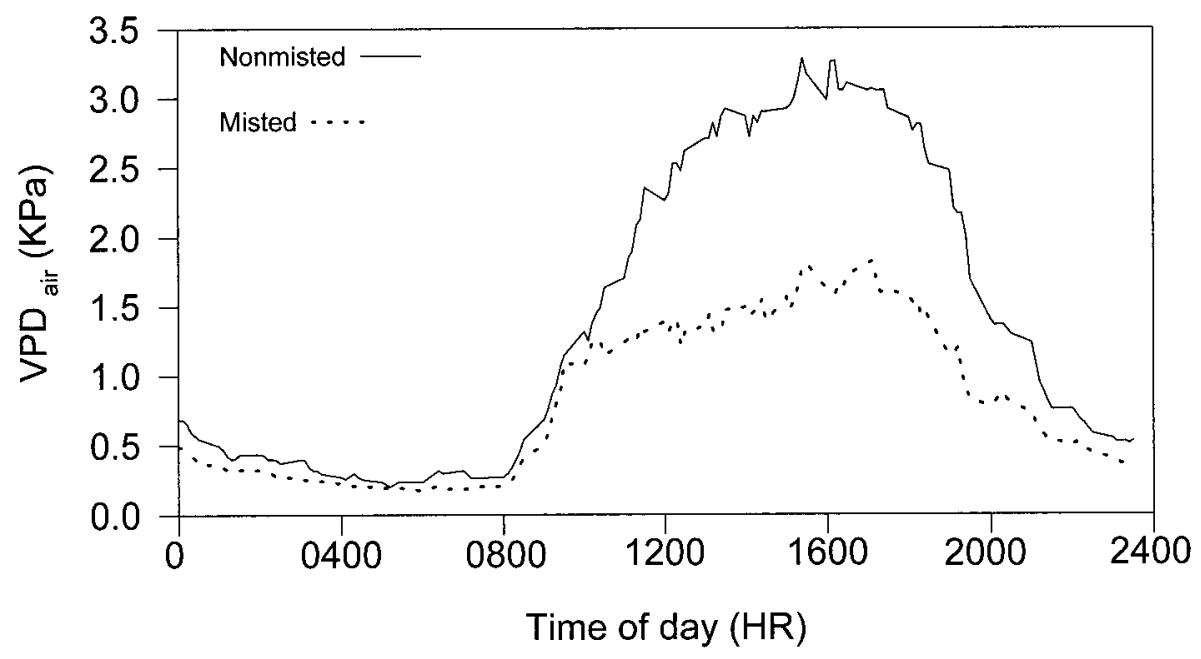




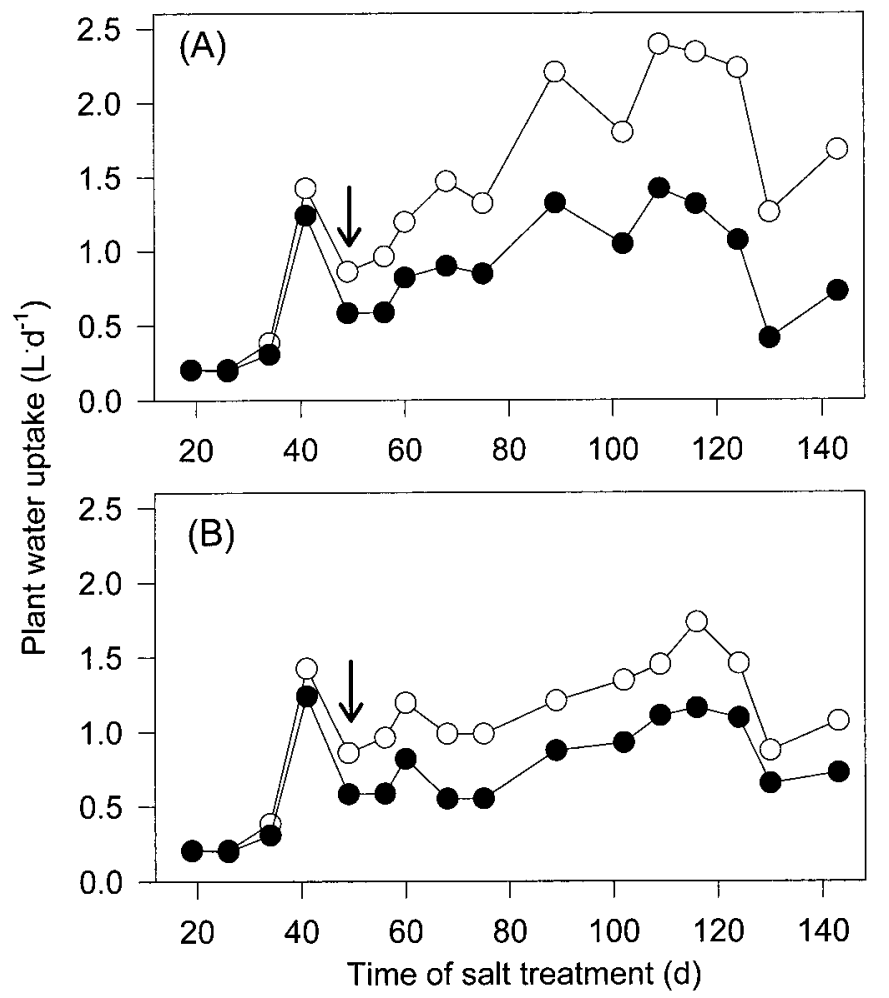

$\longleftarrow$ March $\underset{\text { April }}{\star}$ May $\underset{\text { June }}{\star} \underset{\text { July }}{\rightleftarrows}$

Fig. 2. Daily water uptake from root medium of 'Daniela' tomato plants grown with 0 (open symbols) or with $50 \mathrm{~mm} \mathrm{NaCl}$ (closed symbols) supplied to the nutrient solution, under (A) nonmist and (B) mist treatments of the greenhouse atmosphere. The arrows indicate the beginning of the greenhouse mist treatment. Each symbol is based on five plants.

solution reduced total plant water uptake, calculated for the whole growing period, from 190 to $121 \mathrm{~L} /$ plant. Maximum diurnal water uptake was recorded at the beginning of June, when plants had developed fruit. At this time, nonmisted, salinized plants consumed $42 \%$ less water than nonmisted, nonsalinized plants. Mist reduced plant water uptake from the root medium regardless of salinity treatments (Fig. 2B). However, there was a significant interaction between salt and mist treatment. Nonsalinized plants lowered their water uptake from 153 to $93 \mathrm{~L} /$ plant $(40 \%)$ during the misting period and the reduction of water uptake of salinized plants in the same period was from 92 to $79 \mathrm{~L} /$ plant (15\%). Since the reduction of cumulative plant water uptake by mist in nonsalinized plants was 60 $\mathrm{L} /$ plant and water input from mist was $29 \mathrm{~L} /$ plant, mist saved $31 \mathrm{~L} /$ plant under nonsaline growth conditions.

LEAF WATER STATUS AND GAS EXCHANGE. $\Psi_{\mathrm{w}}$ in the morning was about -0.12 and $-0.18 \mathrm{MPa}$ for nonsalinized and salinized plants, respectively, but there was no significant difference between saline or mist treatments. Although ample water was supplied to the root medium, there were significant differences in midday $\Psi_{\mathrm{w}}$ between saline and mist treatments (Table 1). Midday $\Psi_{\mathrm{w}}$ of salinized plants were $50 \%$ lower than $\Psi_{\mathrm{w}}$ of nonsalinized plants. With mist, $\Psi_{\mathrm{w}}$ was about $40 \%$ higher in nonsalinized and salinized plants. The significant interaction between saline and mist treatments, indicated that salinized plants grown with mist had similar $\Psi_{\mathrm{w}}$ as nonsalinized plants grown without mist. $\Psi \pi$ was $2 \%$ to $4 \%$ higher in the morning than at midday and was reduced about $0.2 \mathrm{MPa}$ by salinity. Midday $\Psi_{\mathrm{p}}$ values were significantly lower than those from early morning. At early morning, $\Psi_{\mathrm{p}}$ values were slightly lower in salinized- nonmisted plants although no significant difference was found between saline or mist treatments. At midday, however, $\Psi_{\mathrm{p}}$ was lowered by saline treatments (Table 1). Mist significantly enhanced leaf turgor during the warmest, driest hours of the day. The increase of $\Psi_{\mathrm{p}}$ with mist was highest in salinized plants for which even some negative $\Psi_{\mathrm{p}}$ were estimated under nonmist growth conditions. Midday leaf $\Psi_{\mathrm{p}}$ was positively correlated to total plant leaf area $(r$ $=0.99)$ and to total DW $(r=0.89)$ but to a lesser extent to yield $(r$ $=0.78)$.

Under nonmist growth conditions, $\mathrm{A}, \mathrm{g}_{\mathrm{s}}$, and $\mathrm{E}$ were reduced by saline irrigation, while $\mathrm{VPD}_{\text {leaf-to-air }}$ was significantly increased (Table 2). Mist significantly reduced $\mathrm{VPD}_{\text {leaf-to-air }}$ in all plants and, hence, resulted in an overall improvement of gas exchange parameters. In the case of salinized plants, mist increased gas exchange parameters to similar levels of those of nonsalinized-misted plants. Leaf WUE was increased by mist up to $84 \%$ to $100 \%$ in nonsalinized and salinized plants, respectively.

Plant GRowTH AND YIELD. Salinity reduced DW of the leaves by $30 \%$, stem DW by $50 \%$, and plant height by $10 \%$ in plants grown without mist (Table 3). However, plants grown with mist showed no salinity-induced decrease in growth. Root DW was not affected by mist and was not significantly increased by salinity. Mist increased total plant leaf area of nonsalinized plants by $39 \%$ and doubled the leaf area of salinized plants. Since the number of leaves perplant was unchanged by salinity or mist treatments, the increase in leaf area with mist was due to the larger size of individual leaves.

Foliar concentration of $\mathrm{Na}$ increased with the saline irrigation and was greater in nonmisted plants than in misted ones (Table 3). This should be related to the lower water uptake from the root medium of salinized plants under mist growth conditions, which consequently reduced plant salt uptake. The increase in leaf $\mathrm{Na}$ by misting was not significant reflecting the low $\mathrm{Na}$ concentration in the mist water.

Total yield of nonsalinized plants increased $18 \%$ with mist while yield of salinized plants was increased more than twice with mist (Table 4). Mist increased fruit weight $15 \%$ in non salinized plants and doubled fruit weight of salinized plants. The number of fruit was significantly reduced by salinity in nonmisted plants but was unaffected in misted plants.

\section{Discussion}

Under our greenhouse conditions, extremely high $\mathrm{VPD}_{\text {air }}$ during the midday period was substantially greater than the 0.5 to

Table 1. Midday leaf water potential $\left(\Psi_{w}\right)$, leaf osmotic potential $(\Psi \pi)$, and leaf turgor potential $(\Psi \pi)$ of 'Daniela' tomato grown with $(S)$ and without (NS) $50 \mathrm{mM} \mathrm{NaCl}$ supplied to the nutrient solution, and with (M) and without (NM) mist of the greenhouse atmosphere.

\begin{tabular}{lccr}
\hline \hline Treatment & $\begin{array}{c}\Psi_{\mathrm{w}} \\
(\mathrm{MPa})\end{array}$ & $\begin{array}{c}\Psi \pi \\
(\mathrm{MPa})\end{array}$ & $\begin{array}{c}\Psi \pi \\
(\mathrm{MPa})\end{array}$ \\
\hline NS-NM & $-1.00 \mathrm{~b}^{\mathrm{z}}$ & $-0.98 \mathrm{~b}$ & $0.02 \mathrm{c}$ \\
S-NM & $-1.48 \mathrm{c}$ & $-1.25 \mathrm{c}$ & $-0.22 \mathrm{~d}$ \\
NS-M & $-0.59 \mathrm{a}$ & $-0.80 \mathrm{a}$ & $0.21 \mathrm{a}$ \\
S-M & $-0.93 \mathrm{~b}$ & $-1.02 \mathrm{~b}$ & $0.10 \mathrm{~b}$ \\
ANOVA & & & $* *$ \\
\multicolumn{1}{c}{ Salinity } & $* *$ & $* *$ & $* *$ \\
\multicolumn{1}{c}{ Mist } & $* *$ & $* *$ & NS \\
\hline
\end{tabular}

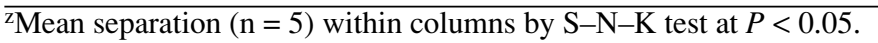
Ns,*,** Nonsignificant or significant at $P<0.05$ or 0.01 , respectively. 
Table 2. Net $\mathrm{CO}_{2}$ assimilation rate $(\mathrm{A})$, stomatal conductance $\left(\mathrm{g}_{\mathrm{s}}\right)$, transpiration rate $(\mathrm{E})$, leaf-to-air vapor pressure deficit $\left(\mathrm{VPD}_{\text {leaf-to-air }}\right.$ ), and water use eficiency (WUE) of 'Daniela' tomato plants grown with (S) and without (NS) $50 \mathrm{mM} \mathrm{NaCl}$ supplied to the nutrient solution, and with (M) and without (NM) mist of the greenhouse atmosphere.

\begin{tabular}{|c|c|c|c|c|c|}
\hline Treatment & $\begin{array}{c}\mathrm{A} \\
\left(\mathrm{CO}_{2}, \mu \mathrm{mol} \cdot \mathrm{m}^{-2} \cdot \mathrm{s}^{-1}\right)\end{array}$ & $\begin{array}{c}\mathrm{g}_{\mathrm{s}} \\
\left(\mathrm{H}_{2} \mathrm{O}, \mathrm{mmol} \cdot \mathrm{m}^{-2} \cdot \mathrm{s}^{-1}\right)\end{array}$ & $\begin{array}{c}\mathrm{E} \\
\left(\mathrm{H}_{2} \mathrm{O}, \mathrm{mol} \cdot \mathrm{m}^{-2} \cdot \mathrm{s}^{-1}\right) \\
\end{array}$ & $\begin{array}{l}\mathrm{VPD}_{\text {leaf-to-air }} \\
(\mathrm{KPa})\end{array}$ & $\begin{array}{c}\text { WUE } \\
\left(\mu \mathrm{mol} \mathrm{CO} / \mathrm{mol} \mathrm{H}_{2} \mathrm{O}\right)\end{array}$ \\
\hline$\overline{\mathrm{NS}-\mathrm{NM}}$ & $24 b^{z}$ & $381 \mathrm{c}$ & $11.5 \mathrm{a}$ & $2.8 \mathrm{~b}$ & $2.1 \mathrm{c}$ \\
\hline S-NM & $8 \mathrm{c}$ & $153 \mathrm{~d}$ & $4.9 \mathrm{~d}$ & $3.3 \mathrm{a}$ & $1.6 \mathrm{~d}$ \\
\hline S-M & $31 \mathrm{a}$ & $462 \mathrm{a}$ & $9.4 \mathrm{~b}$ & $2.0 \mathrm{c}$ & $3.3 \mathrm{~b}$ \\
\hline \multicolumn{6}{|l|}{ ANOVA } \\
\hline Salinity & $* *$ & $* *$ & $* *$ & $* *$ & $* *$ \\
\hline Salinity $\times$ mist & $* *$ & $* *$ & $* *$ & $*$ & NS \\
\hline
\end{tabular}

${ }^{\mathrm{z}}$ Mean separation $(\mathrm{n}=5)$ within columns by $\mathrm{S}-\mathrm{N}-\mathrm{K}$ test at $P<0.05$.

Ns,*,** Nonsignificant or significant at $P<0.05$ or 0.01 , respectively.

Table 3. Dry weight of leaves, stems, and roots, plant height, number of leaves, total plant leaf area, and foliar Na of 'Daniela' tomato plants grown with (S) and without (NS) $50 \mathrm{mM} \mathrm{NaCl}$ supplied to the nutrient solution, and with (M) and without (NM) mist of the greenhouse atmosphere.

\begin{tabular}{|c|c|c|c|c|c|c|c|}
\hline Treatment & $\begin{array}{c}\text { Leaves } \\
\text { (g) }\end{array}$ & $\begin{array}{c}\text { Stems } \\
(\mathrm{g})\end{array}$ & $\begin{array}{c}\text { Roots } \\
\text { (g) }\end{array}$ & $\begin{array}{l}\text { Plant ht } \\
(\mathrm{cm})\end{array}$ & $\begin{array}{c}\text { Leaves } \\
\text { (no.) }\end{array}$ & $\begin{array}{c}\text { Total plant } \\
\text { leaf area } \\
\left(\mathrm{cm}^{2}\right)\end{array}$ & $\begin{array}{c}\text { Foliar } \\
\mathrm{Na} \\
(\% \mathrm{DW})\end{array}$ \\
\hline$\overline{\mathrm{NS}-\mathrm{NM}}$ & $96 b^{z}$ & $122 \mathrm{a}$ & $19 \mathrm{a}$ & $259 \mathrm{ab}$ & $37 \mathrm{a}$ & $12088 \mathrm{c}$ & $0.08 \mathrm{c}$ \\
\hline NS-M & $117 \mathrm{a}$ & $121 \mathrm{a}$ & $18 \mathrm{a}$ & $259 a b$ & $39 a$ & $16662 \mathrm{a}$ & $0.17 \mathrm{c}$ \\
\hline S-M & $123 \mathrm{a}$ & $122 \mathrm{a}$ & $25 \mathrm{a}$ & $265 \mathrm{a}$ & $40 \mathrm{a}$ & $13967 \mathrm{~b}$ & $0.63 \mathrm{~b}$ \\
\hline Mist & $* *$ & $* *$ & NS & $*$ & $* *$ & $* *$ & $* *$ \\
\hline Salinity $\times$ mist & $* *$ & $* *$ & NS & NS & NS & $* *$ & $* *$ \\
\hline
\end{tabular}

${ }^{\mathrm{z}}$ Mean separation $(\mathrm{n}=5)$ within columns by S-N-K test at $P<0.05$. Ns,*,** Nonsignificant or significant at $P<0.05$ or 0.01 , respectively.

Table 4. Yield, individual fruit weight, and total number of fruit per plant of 'Daniela' tomato grown with (S) and without (NS) $50 \mathrm{mM} \mathrm{NaCl}$ supplied to the nutrient solution, and with (M) and without (NM) mist of the greenhouse atmosphere.

\begin{tabular}{lcrc}
\hline \hline Treatment & $\begin{array}{c}\text { Yield } \\
(\mathrm{kg} / \text { plant })\end{array}$ & $\begin{array}{c}\text { Fruit wt } \\
(\mathrm{g})\end{array}$ & $\begin{array}{c}\text { Fruit } \\
\text { no. }\end{array}$ \\
\hline NS-NM & $5.8 \mathrm{~b}^{\mathrm{z}}$ & $125 \mathrm{~b}$ & $47 \mathrm{a}$ \\
S-NM & $1.7 \mathrm{~d}$ & $53 \mathrm{~d}$ & $32 \mathrm{~b}$ \\
NS-M & $7.1 \mathrm{a}$ & $139 \mathrm{a}$ & $51 \mathrm{a}$ \\
S-M & $3.7 \mathrm{c}$ & $85 \mathrm{c}$ & $44 \mathrm{a}$ \\
ANOVA & & & \\
$\quad$ Salinity & $* *$ & $* *$ & $* *$ \\
$\quad$ Mist & $* *$ & $* *$ & $* *$ \\
\multicolumn{1}{c}{ Salinity $\times$ mist } & $*$ & $* *$ & NS
\end{tabular}

${ }^{\mathrm{z}}$ Mean separation $(\mathrm{n}=5)$ within columns by S-N-K test at $P<0.05$. Ns, ${ }^{* * *}$ Nonsignificant or significant at $P<0.05$ or 0.01 , respectively.

$0.7 \mathrm{kPa}$ recommended for tomato (Bakker, 1990). Mist lowered average $\mathrm{VPD}_{\text {air }}$ during the driest hours of the day by $50 \%$, thereby improving growth conditions for tomato as reflected by the significant increase of total plant growth and fruit yield with mist. We observed a significant increase in leaf area with mist, however, smaller tomato leaves have been reported as a consequence of increasing humidity within the greenhouse (Holder and Cockshull, 1990; Iraqui et al., 1997). These contradictory results could be explained by the level of stress in these previous studies where very low $\mathrm{VPD}_{\text {air }}$ (from 0.1 to $0.8 \mathrm{kPa}$ ) resulted in low transpiration rates. Under very low $\mathrm{VPD}_{\text {air }}$, the limiting factor for leaf expansion could be low Ca absorption (Ho, 1989; Holder and Cocksull, 1988).

Mist reduced water uptake from the root medium of nonsalinized plants by $40 \%$, as a consequence of lower atmospheric water demand induced by the lower $\mathrm{VPD}_{\text {air }}$. The lower reduction $(15 \%)$ of plant water uptake by mist in salinized plants must have been related to the significant increase of shoot growth and yield with mist by these plants. The better water status and the lower toxic effect of salinity in salinized-misted plants possibly affected internal water allocation to storage in fruit. Previous studies have shown that water consumption of tomato plants under saline growth conditions was related to lowering of root hydraulic conductivity (Rodríguez et al., 1997) and to saltinduced reduction of shoot growth, stomatal density, and transpiration rates (Romero-Aranda et al., 2000).

Stomata can respond directly to $\mathrm{VPD}_{\text {leaf-to-air }}$ and local water deficits in the leaf can result in stomatal closure (Grantz, 1990; Maroco et al., 1997). Data reported herein show that greenhouse mist significantly reduced $\mathrm{VPD}_{\text {leaf-to-air }}$ and increased $\mathrm{gs}, \Psi_{\mathrm{w}}$, and $\Psi_{\mathrm{p}}$. The fact that mist completely overcame the effect of saline irrigation on gas exchange parameters could have been a consequence of the combined effects of mist that reduced $\mathrm{VPD}_{\text {leaf-to-air }}$ and plant water uptake thereby reducing salinity stress. The improved leaf water status and the higher $\mathrm{g}_{\mathrm{s}}$, along with the lower foliar Na content of salinized-misted plants, resulted in a significant increase of A and WUE in all misted plants.

Cell turgor has been associated with the plant's ability to maintain growth during saline or drought stress conditions (Munns, 1993). Although the existence of negative turgor pressure is still a matter of debate (Rhizopoulou, 1997), results supporting this hypothesis have been reported (Grammatikopoulos, 1999; 
Kimberley and Davis, 1994). The very high atmospheric evaporative demand at midday, under greenhouse conditions, resulted in loss of leaf turgidity to zero. The negative leaf turgor estimated for some salinized, nonmisted plants could be attributed to leaf dehydration (Markhart et al., 1981). In addition to the increase in foliar Na concentration that could induce toxicity and nutritional imbalance, the decrease of leaf $\Psi_{\mathrm{p}}$ with loss of turgidity during the driest hours of the day could have contributed to reduced leaf development in salinized plants. On the other hand, leaf $\Psi_{\mathrm{w}}$ and leaf $\Psi_{\mathrm{p}}$ were significantly increased by mist which supports the idea that $\Psi$ responds to $\mathrm{VPD}_{\text {air }}$ (Grammatikopoulos and Manetas, 1994).

The major long-term effect of high humidity on greenhouse crops has been postulated to influence leaf area because biomass production is positively related to leaf area (Papadopulos et al., 1997). In tomato, yield has been correlated with photosynthetic leaf area (Slack, 1986; Wiebe, 1970) and fruit growth has been associated with the amount of assimilate imported from nearby leaves (Shishido and Hori, 1977). However, we observed a $44 \%$ and $17 \%$ reduction of total leaf area in salinized plants grown without and with mist, respectively. These reductions were associated with $70 \%$ and $48 \%$ yield reductions. Thus, yield reduction was unlikely to be due only to differences in leaf area and/or assimilate production but to water distribution in the plant. Water taken up by the plants under dry atmospheric conditions was probably first used to meet transpiration requirements and secondarily allocated to fruit growth as suggested by Ehret and Ho (1986) and Johnson et al. (1992).

In summary, extreme high atmospheric evaporative demand is common inside greenhouses in the Mediterranean region, especially around midday. Such large $\mathrm{VPD}_{\text {air }}$ can be lowered by a simple mist system thereby increasing $\mathrm{g}_{\mathrm{s}}$, growth, and yield even under salinity stress. If saline water must be used for irrigation, mist with high quality water can alleviate salinity effects by reducing saline water uptake from soil. Under both saline or nonsaline growth conditions, mist improved plant water status and increased yield along with achieving a significant savings of water.

\section{Literature Cited}

Bakker, J.C. 1990. Effects of day and night humidity on yield and fruit quality of glasshouse tomatoes. J. Hort. Sci. 65:323-331.

Cánovas, F. 1995. Manejo del cultivo sin suelo, p. 227-254. In: F. Nuez (ed.). El cultivo del tomate. Mundi-Prensa, Madrid, Spain.

Cuartero, J. and R. Fernandez-Muñoz. 1999. Tomato and salinity. Scientia Hort. 78:83-125.

Ehret, D.L. and L.C. Ho. 1986. Effects of osmotic potential in nutrient solution on diurnal growth of tomato fruit. J. Expt. Bot. 37:1294-1302.

Grammatikopoulos, G. 1999. Mechanisms for drought tolerance in two Mediterranean seasonal dimorphic shrubs. Austral. J. Plant Physiol. 26:587-593.

Grammatikopoulos, G and Y. Manetas. 1994. Direct absorption of water by hairy leaves of Phlomis fruticosa and its contribution to drought avoidance. Can. J. Bot. 72:1805-1811.

Grange, R.I. and D.W. Hand. 1987. A review of the effects of atmospheric humidity on the growth of horticultural crops. J. Hort. Sci. 62:125-134.
Grantz, D.A. 1990. Plant response to atmospheric humidity. Plant Cell Environ. 13:667-679.

Ho, L. 1989. Environmental effects on the dirunal accumulation of ${ }^{45} \mathrm{Ca}$ by young fruit and leaves of tomato plants. Ann. Bot. 63:281-288.

Holder, R. and K.E. Cocksull. 1988. The effect of humidity and nutrition on the development of calcium deficiency symptoms in tomato leaves, p. 53-60. In: K.E. Cocksull (ed.). The effects of high humidity on plant growth in energy-saving greenhouses. Euro. Comm. Serv. Comunication, Brussels, Belgium.

Holder, R. and K.E. Cocksull. 1990. Effect of humidity on the growth and yield of glasshouse tomatoes. J. Hort. Sci. 65:31-39.

Iraqui, D., L. Gauthier, M. Dorais, and A. Gosselin. 1997. Influence du déficit de pression de vapeur et de la photopériode sur la croissance, la productivité et la composition minérale de la tomate de serre. Can. J. Plant Sci. 77:267-272.

Johnson, R.W., M.A. Dixon, and D.R. Lee. 1992. Water relations of the tomato during fruit growth. Plant Cell Environ. 15:947-953.

Jones, H.G. and J.E. Corlett. 1992. Current topics in drought physiology. J. Agr. Sci. 119:291-296.

Kimberley, J.K. and S.D. Davis. 1994. Drought tolerance and xylem embolism in co-occuring species of coastal sage and chaparral. Ecology 75:648-659.

Markhart, A.H., N. Sionit, and J.N. Siedow. 1981. Cell wall water dilution: An explanation of apparent negative turgor potentials. Can. J. Bot. 59:1722-1725.

Maroco, J.P., J.S. Pereira, and M.M. Chaves. 1997. Stomatal responses to leaf-to-air vapour pressure deficit in sahelian species. Austral. J. Plant Physiol. 24:381-387.

Monteith, J.L. 1995. A reinterpretation of stomatal responses to humidity. Plant Cell Environ. 18:357-364.

Munns, R. 1993. Physiological processes limiting plant growth in saline soils: Some dogmas and hypotheses. Plant Cell Environ. 16:15-24.

Nonami, H., E.D. Schulze, and H. Ziegler. 1990. Mechanisms of stomatal movement in response to air humidity, irradiance and xylem water potential. Planta 83:57-64.

Papadopoulos, A.P., S. Pararajasingham, J.L. Shipp, W.R. Jarvis, and T.J. Jewett. 1997. Integrated management of greenhouse vegetable crops. Hort. Rev. 21:1-39.

Rhizopoulou, S. 1997. Is negative turgor fallacious? Physiol. Plant. 99:505-510.

Rodríguez, P., J. Dell'Amigo, D. Morales, M.J. Sánchez-Blanco, and J.J. Alarcón. 1997. Effects of salinity on growth, shoot water relations and root hydraulic conductivity in tomato plants. J. Agr. Sci. 128:439-444.

Romero-Aranda, R., T. Soria, and J. Cuartero. 2000. Tomato plant-water uptake and plant-water relationships under saline growth conditions. Plant Sci. 160:265-272.

Schulze, E.D. 1994. The regulation of plant transpiration: Interactions of feedforward, feedback and futile cycles, p. 203-235. In: E.D. Schulze (ed.). Flux control in biological systems: From enzymes to populations and ecosystems. Academic Press, New York.

Shishido, Y. and Y. Hori. 1977. Studies on translocation and distribution of photosynthetic assimilates in tomato plants. II. Distribution patterns as affected by phyllotaxis. J. Agr. Res. 30:87-94.

Slack, G. 1986. The effects of leaf removal on the development and yield of glasshouse tomatoes. J. Hort. Sci. 61:353-360.

Stanghellini, C. 1994. Environmental effect on growth and its implications for climate management in Mediterranean greenhouses. Acta Hort. 361:57-66.

Wiebe, J. 1970. Foliage canopy effects in greenhouse tomatoes. Rpt. Hort. Res. Inst., Ontario, Canada. p. 108-113. 